\title{
Impacts of savanna trees on forage quality for a large African herbivore
}

\author{
Fulco Ludwig · Hans De Kroon · Herbert H. T. Prins
}

Received: 4 May 2007/Accepted: 24 September 2007/Published online: 29 February 2008

(C) The Author(s) 2008

\begin{abstract}
Recently, cover of large trees in African savannas has rapidly declined due to elephant pressure, frequent fires and charcoal production. The reduction in large trees could have consequences for large herbivores through a change in forage quality. In Tarangire National Park, in Northern Tanzania, we studied the impact of large savanna trees on forage quality for wildebeest by collecting samples of dominant grass species in open grassland and under and around large Acacia tortilis trees. Grasses growing under trees had a much higher forage quality than grasses from the open field indicated by a more favourable leaf/stem ratio and higher protein and lower fibre concentrations. Analysing the grass leaf data with a linear programming model indicated that large savanna trees could be essential for the survival of wildebeest, the dominant herbivore in Tarangire. Due to the high fibre content and low nutrient and protein concentrations of grasses from the open field, maximum fibre intake is reached before nutrient requirements are satisfied. All requirements can only be satisfied by combining forage from open grassland with either forage from under or around tree canopies. Forage quality was also higher around dead trees than in the open field. So forage
\end{abstract}

Communicated by Roland Brandl.

F. Ludwig $(\varangle) \cdot$ H. De Kroon $\cdot$ H. H. T. Prins

Department of Environmental Sciences, Wageningen University,

Droevendaalsesteeg 4, 6708 PB Wageningen, The Netherlands

e-mail: fulco.ludwig@wur.nl

H. De Kroon

Department of Ecology, Radboud University Nijmegen,

Toernooiveld, 6525 ED Nijmegen, The Netherlands quality does not reduce immediately after trees die which explains why negative effects of reduced tree numbers probably go initially unnoticed. In conclusion our results suggest that continued destruction of large trees could affect future numbers of large herbivores in African savannas and better protection of large trees is probably necessary to sustain high animal densities in these ecosystems.

Keywords Acacia tortilis · Nutrients ·

Plant-animal interactions · Tree-grass interactions .

Wildebeest

\section{Introduction}

Savanna ecosystems are characterized by a continuous grass layer interspersed with trees and shrubs. The density and diversity of large herbivores is very high in African savannas and many pastoral communities depend on seminatural savannas through livestock grazing (Prins and Olff 1998; Olff et al. 2002). The effects savanna trees have on understorey grass productivity have been a focus of research for decades, and both negative and positive effects have been described (Belsky et al. 1989; 1993; Mordelet and Menaut 1995; Ludwig et al. 2001; 2004a). Trees reduce grass growth by competing with grasses for water, light and nutrients (Scholes and Archer 1997; Anderson et al. 2001; Ludwig et al. 2001, 2004b), but trees can also improve grass production through hydraulic lift (Caldwell et al. 1998; Ludwig et al. 2003), reduced evapotranspiration (Amundson et al. 1995: Ludwig et al. 2001) and increased nutrient availability (Scholes and Archer 1997; Ludwig et al. 2004a). Although total plant production affects animal biomass, forage quality is of much more 
importance for understanding herbivore performance and food limitation (Van Soest 1994) and the interplay between forage quality and quantity determines to a large extent the composition of the herbivore assemblage (Prins and Olff 1998; Olff et al. 2002). Two previous studies which compared forage quality under trees and in the open field both report higher forage quality under Acacia (Belsky 1992) and Eucalyptus (Jacskon and Ash 1998) trees. Increased forage quality is probably caused by higher soil nutrient concentrations under tree canopies (Kellman 1979; Belsky et al. 1989; Scholes and Archer 1997). Also water competition and shade could increase forage quality because nutrients taken up by grasses are less diluted due to a lower biomass production.

Currently, large tree cover is decreasing in several African savannas due to high elephant pressure and frequent fires (Eckhardt et al. 2000). In Tarangire National Park (NP) (northern Tanzania) the cover of large trees declined from 20\% in 1970, to only 5\% in 1996 (Van de Vijver et al. 1999). A recent study in Namibia showed that the number of large trees was reduced by $50 \%$ over the last 36 years while the extent of shrubland dramatically increased (Mosugelo et al. 2002). Also in Kruger NP (South Africa) and in the Serengeti-Masai Mara ecosystem (Tanzania and Kenya) the number of large trees in savannas has decreased over the last decades (Ruess and Halter 1990; Eckhardt et al. 2000). Outside protected areas the situation is often even more dramatic, with most of the large trees being removed by local people for production of charcoal (Kituyi et al. 2001; Luoga et al. 2002). Reductions in tree cover could have serious consequences if trees have a positive effect on herbivore food quality and availability.

The objective of this study was to investigate the impact of trees on forage quality and how a reduction in the number of large trees could affect herbivore populations in African savannas. Specifically, we focussed on the impact of the dominant East African savanna tree, Acacia tortilis, on nutrient concentrations, protein content and digestibility of grasses. We included small, large and dead trees in our study to be able to determine how large tree destruction affects forage quality through time. A linear programming model was used to test the hypothesis that forage growing under trees is necessary for the long-term survival of wildebeest, the dominant large herbivore in East African savannas.

\section{Materials and methods}

\section{Site description}

Data were collected in Tarangire NP $\left(4^{\circ} \mathrm{S}, 37^{\circ} \mathrm{E}, 1,200 \mathrm{~m}\right.$ above sea level) which is located at the eastern side of the Great Rift Valley in northern Tanzania and encompasses an area of about $2,600 \mathrm{~km}^{2}$. Mean rainfall is $650 \mathrm{~mm} / \mathrm{year}$ (Van de Vijver 1999). The wet season is from November until May with most of the rain typically falling during March and April. The Tarangire River runs through the park, and in the dry season this river is the main permanent fresh water supply within the entire $35,000 \mathrm{~km}^{2}$ Masai ecosystem (Prins 1987).

Northern Tarangire NP is in the dry season range of large migratory herds of Burchell's zebra (Equus burchelli) and wildebeest (Connochaetes taurinus) and to a lesser extent Cape buffalo (Syncerus caffer). Towards the end of the dry season Northern Tarangire has one of the highest concentrations of large herbivores in the world. At the beginning of the wet season wildebeest and zebra leave Tarangire NP to graze on the Simanjiro Plains. During most years both species give birth and lactate on the $\mathrm{Si}$ manjiro plains and return to Tarangire NP in the dry season (Voeten and Prins 1999). The park is also famous for its large herds of elephants (Loxodonta africana) which primarily reside in the park during the dry season and sometimes disperse to surrounding areas in the wet season. The number of large elephants has increased sharply over the last 20 years due to destruction of habitat outside the park which forced more elephants into Tarangire NP.

Two wooded savanna types dominate the park: Acacia savanna, which can be found in the riverine area with lacustrine soils in which A. tortilis is the dominant tree species, and the deciduous savanna, which is concentrated on the ridges and upper slopes on Precambrian well drained red loamy soils (see Van de Vijver et al. 1999). Here, the dominating trees are Combretum and Commiphora species. Most of the herbivores concentrate in the Acacia savanna (Tarangire Conservation Project 1997, Voeten 1999), presumably because of the higher forage quality, so we focused our work on this savanna type. As A. tortilis accounts for $90 \%$ of the large trees in this savanna type (Van de Vijver et al. 1999) we focused our study on grass vegetation growing under and around this tree species. Total woody cover, including bushes, is about $20 \%$, and especially the cover of large trees has declined over the last 30 years (Van de Vijver et al. 1999).

Grass sample collection and chemical analyses

A study site of $2 \times 2 \mathrm{~km}$ was selected with a vegetation which was representative of the Acacia savanna in Tarangire NP. The study site was located between the main entrance of the Tarangire NP and the park headquarters. For this study the same four large trees were used as described in Ludwig et al. (2004a). Trees were selected on the basis that they were separated from other large trees by at least $100 \mathrm{~m}$ and $50 \mathrm{~m}$ from any bushes or small trees. Trees close to termite hills were avoided. Measurements 
Table 1 Average (SD in parentheses, $n=4$ ) vegetation cover, live and dead stems and leaves and leaf/stem ratio of grass species growing under and around canopies of large Acacia tortilis trees and in open grassland patches

\begin{tabular}{|c|c|c|c|c|c|c|c|}
\hline $\begin{array}{l}\text { Location } \\
\text { Data }\end{array}$ & Species & $\begin{array}{l}\text { Cover of vegetation } \\
\text { at specific zone }(\%)\end{array}$ & $\begin{array}{l}\text { Live } \\
\text { stem }(\%)\end{array}$ & $\begin{array}{l}\text { Live } \\
\text { leaf }(\%)\end{array}$ & $\begin{array}{l}\text { Dead } \\
\text { stem }(\%)\end{array}$ & $\begin{array}{l}\text { Dead } \\
\text { leaf }(\%)\end{array}$ & $\begin{array}{l}\text { Leaf/stem } \\
\text { ratio }\end{array}$ \\
\hline \multirow[t]{3}{*}{ Under tree canopy } & Panicum maximum & 9 & $33.1(5)$ & $51.1(13)$ & $4.5(6)$ & $11.3(4)$ & $1.81(0.73)$ \\
\hline & Cynodon spp. & 62 & $47.4(7)$ & $42.0(8)$ & $4.4(2)$ & $6.2(3)$ & $0.95(0.24)$ \\
\hline & Cenchrus ciliaris & 9 & $40.8(15)$ & $28.3(9)$ & $6.8(3)$ & $24.0(13)$ & $1.22(0.54)$ \\
\hline \multirow[t]{6}{*}{ Around tree canopy } & Cynodon spp. & 7 & $50.4(6)$ & $25.4(3)$ & $5.4(3)$ & $18.8(7)$ & $0.80(0.14)$ \\
\hline & Cenchrus ciliaris & 6 & 40.9 (19) & $27.2(3)$ & $15.4(10)$ & $16.5(10)$ & $0.83(0.37)$ \\
\hline & Digitaria macroblephera & 14 & $39.0(15)$ & $25.2(8)$ & $7.9(15)$ & $27.8(3)$ & $0.70(0.24)$ \\
\hline & Chloris virgata & 9 & $43.7(7)$ & $30.7(8)$ & $9.0(6)$ & $16.6(6)$ & $1.14(0.12)$ \\
\hline & Urochloa mosambicencis & 21 & $52.4(3)$ & $34.7(11)$ & $4.9(5)$ & $8.0(10)$ & $0.91(0.20)$ \\
\hline & Heteropogon contortis & 17 & $43.8(6)$ & $27.2(9)$ & $15.9(4)$ & $13.1(3)$ & $0.77(0.25)$ \\
\hline \multirow[t]{2}{*}{ Open grassland } & H. contortis & 38 & $48.3(4)$ & $32.9(7)$ & $8.4(5)$ & $10.4(5)$ & $0.77(0.11)$ \\
\hline & Sehima nervosum & 36 & $50.1(12)$ & $29.2(9)$ & $12.0(7)$ & $8.7(14)$ & $0.62(0.16)$ \\
\hline Statistics $^{\mathrm{a}}$ & & $d f$ & & & & & \\
\hline Location & $F$ & 2,38 & 1.76 & $6.57 * *$ & 1.86 & 1.84 & $8.60 * * *$ \\
\hline Tree (block) & $F$ & 3,38 & 1.60 & 0.42 & 1.18 & 0.08 & 1.15 \\
\hline
\end{tabular}

** $P<0.01, * * * P<0.001$

${ }^{a}$ Variance of data was analysed with a general linear model (GLM) with grass species and location (open grassland and under and around canopies) as fixed factors

and calculations by Prins and Van der Jeugd (1993) suggest that these trees are ca. 100 years old. Trees have a canopy diameter between 15 and $25 \mathrm{~m}$. A previous study showed that around large trees, three different vegetation zones of the herbaceous layer can be distinguished, namely: (1) under large tree canopies, (2) just outside tree canopy projections (called "around tree canopies"), and (3) in open patches more than $50 \mathrm{~m}$ from any tree (Ludwig et al. 2004a).

Species composition was recorded at peak standing biomass during the early dry season in June 2000 in 20 different $2 \times 2-\mathrm{m}$ plots in each of the three different communities. For each plot the cover of all grass species was visually estimated. Nomenclature followed Clayton and Renvoize (1982). Under tree canopies, plots were located in between the tree stem and canopy edge. Plots around tree canopies were selected at twice the distance from the stem, as the edge of the tree crown. For example, if the canopy edge was at $10 \mathrm{~m}$ from the trunk the centre of the plot under the canopy was located at $5 \mathrm{~m}$ from the trunk and the plot "around canopies" at $20 \mathrm{~m}$ from the trunk. Open grassland plots were at least $50 \mathrm{~m}$ from any tree.

To analyse grass nutrient concentration, grass samples were collected in the early dry season in June 2000, because this is the time of year when migratory herds of wildebeest and zebra return to Tarangire NP and start grazing at the study site. At each of the three different vegetation zones around large trees, samples of the most abundant grass species were collected. Different species were sampled in the three zones because of differences in species compositions. See Table 1 for species sampled in each zone. Three Cynodon species, Cynodon dactylon, Cynodon nlemfluensis and Cynodon plectostachius, were treated as one group because they are very similar, rarely flower and it is very hard to distinguish between the species without uprooting them and when they are not flowering (see Clayton and Renvoize 1982).

Grass samples were collected following the "hand plucking method" (Wallis de Vries 1995). Samples were plucked between thumb and backward-bent index finger to simulate large herbivore grazing as closely as possible. One sample of every species was collected within each zone. One sample consisted of between 15 and 25 pickings collected in small mono-specific stands at different spots within the same zone. Samples were dried in the sun and sorted into leaves and stems and live and dead material.

After drying at $70^{\circ} \mathrm{C}$ for at least 48 hours, live leaves were analysed for total $\mathrm{N}, \mathrm{P}, \mathrm{K}, \mathrm{Ca}, \mathrm{Mg}$ and $\mathrm{N}$ using a modified Kjeldahl procedure with $\mathrm{Se}$ as a catalyst (Novozamski et al. 1983). After digestion, $\mathrm{N}$ and $\mathrm{P}$ concentrations were measured colorimetrically with a continuous flow analyser (Skalar SA-4000; The Netherlands) and K, Ca, $\mathrm{Mg}$ and $\mathrm{Na}$ were analysed with an atomic absorption spectrophotometer (Varian Spectra AA-600; The Netherlands). Neutral detergent fibre (NDF) was determined according to Goering and Van Soest (1970) and digestibility of organic matter (DOM) according to Tilley and Terry (1963). Crude protein was calculated as $6.25 \times$ total 
$\mathrm{N}$ concentration. DOM, NDF and protein concentration of the vegetation per zone were calculated by multiplying the nutrient concentration in a specific species by its relative abundance within the vegetation.

Dead and smaller trees have a different effect on the understorey vegetation than large trees or open grassland (Ludwig et al. 2004a). To study how large-tree removal affects forage quality through time, grass samples were also collected around dead and smaller A. tortilis trees. Samples of the dominant grass species were collected under bushes, small trees and around dead trees. Welldeveloped "bushes" of A. tortilis were ca. $4 \mathrm{~m}$ high and had no signs of tree or umbrella shape development. "Small trees" had a clear tree form and were about $10 \mathrm{~m}$ tall and had started to form an umbrella shape. "Dead trees" were large trees which had died $4-8$ years ago. For detailed description of tree stages see Ludwig et al. (2004a). Samples were collected as described above and analysed for protein, NDF and DOM.

\section{Linear model}

The problem of having to comply with several different requirements can be analysed with a linear programming model (Belovsky 1978; Voeten 1999). This is an optimization model in which one variable is maximized or minimized, while subjected to different constraints. Here, it is used to study whether herbivores can meet all their nutritional and energy requirements by selecting either food from under or around trees or from open grassland or a combination of food sources. As a basis the model described by Voeten (1999) is used. We used wildebeest as model species because it is the most abundant herbivore in Tarangire NP (Tarangire Conservation Project 1997) and nutrient and energy constraints of this species have partly been described by Murray (1993, 1995). It would be ideal to include more herbivore species but only data for wildebeest are available. Each constraint was formulated as a general linear equation:

$C \geq$ or $\leq \sum c_{i} \times I_{i}$

where $C$ is a constraint value which stands for either nutrient, energy or fibre intake. We formulated minimum requirements for nutrient, protein and energy intake, and a maximum value for fibre intake. $I_{i}$ is the amount of food consumed by class $i$; in this study grass leaves from under or around tree canopies or open grassland. The parameter $c_{i}$ converts $I_{i}$ into the same unit as $C$ and is based on the nutrient, energy and fibre content measured in the grass leaves of the different zones.

Murray (1995) calculated, from a feeding trial in the Serengeti, northern Tanzania, that wildebeest need an energy intake of $22.32 \mathrm{MJ} /$ day for maintenance. This was based on an average body mass of $143 \mathrm{~kg}$. The metabolic energy of grasses equals the digestible energy multiplied by 0.82 (Van Soest 1994). The digestible energy can be calculated from the DOM multiplied by the gross energy of grass. The energy content of grasses averages $19 \mathrm{MJ} / \mathrm{kg}$ DOM (Crampton and Harris 1969), and this number was used for all grass species. Thus the constraint equation for energy intake is:

$22.32(\mathrm{MJ} /$ day $) \leq \sum 19(\mathrm{MJ} / \mathrm{kgDW}) \times \mathrm{DOM}_{i}(\mathrm{~g} / \mathrm{g}) \times 0.82 I_{i}$

where DOM is the digestibility of organic matter as determined in vegetation. $I$ is the intake rate $[\mathrm{kg}$ dry weight (DW)/day] and $i$ stands for the foraging zone.

Digestible protein (DP) requirements at maintenance for ruminants can be calculated as (Voeten 1999):

$\operatorname{DP}(\mathrm{g} /$ day $)=3.150 \times W^{0.75}$

where $W$ stands for metabolic weight $(\mathrm{kg})$. We used an average weight of wildebeest of $143 \mathrm{~kg}$ (Murray 1993) which means they need $130 \mathrm{~g}$ DP per day for maintenance. DP for tropical grasses can be calculated from crude protein using a formula proposed by Prins (1987):

$\mathrm{DP}(\mathrm{mg} / \mathrm{g})=0.91 \times \mathrm{CP}(\mathrm{mg} / \mathrm{g})-32.2$

The second constraint equation used in the model is:

$130 \mathrm{~g} \mathrm{DP} /$ day $\leq \sum \mathrm{DP}_{i} \times I_{i}$.

For ruminants the daily intake rates are often constrained by rate of digestion and passage through the rumen (Voeten 1999). The digestibility rate of food is often correlated with the cell wall content, measured in the vegetation as NDF (Van Soest 1994). Reid et al. (1988) calculated from a feeding trial of cattle on a $\mathrm{C}_{4}$ grass diet that maximum daily NDF intake can be calculated as:

NDF intake $(\mathrm{kg})=66.7 \times 10^{-3} \times W^{0.75}$

For wildebeest of $143 \mathrm{~kg}$, the maximum intake is thus $2.76 \mathrm{~kg}$ NDF so the third constraint equation is:

$2.76 \mathrm{~kg} \mathrm{NDF} /$ day $=\sum \mathrm{NDF}_{i} \times I_{i}$

In addition, two equations were defined based on requirements of the two most important nutrients for wildebeest as determined by Murray (1995). The constraint equation for maintenance levels of $\mathrm{Ca}$ and $\mathrm{P}$ are:

$$
\begin{aligned}
& 5.75 \mathrm{~g} \mathrm{P} / \text { day } \leq \sum \mathrm{P}_{i} \times I_{i} \\
& 3.59 \mathrm{~g} \mathrm{Ca} / \text { day } \leq \sum \mathrm{Ca}_{i} \times I_{i}
\end{aligned}
$$

where $\mathrm{P}$ and $\mathrm{Ca}$ are the concentrations measured in the vegetation. 
$\mathrm{Na}$ is not considered in this model because wildebeest can satisfy their daily requirements through drinking water from the Tarangire River (Voeten 1999). The different constraints were used to calculate whether wildebeest can meet all nutritional and energy requirements for maintenance (to maintain a stable body weight) by selecting forage from different foraging zones. As an input value for each of the three zones a weighted average, depending on plant cover, of the dominant grass species was used. Plant cover instead of biomass was used because only plant cover data were available.

\section{Statistical analysis}

Percentages of dead and live leaves and stems, nutrient concentrations, NDF and DOM of grass samples were analysed with a general linear model (GLM) with vegetation zone (under and around tree canopies, and open grassland) as fixed factors and trees as a random factor. Differences in NDF, DOM and protein concentrations of grasses from different tree stages (open grassland, bushes and small, large and dead trees) were analysed with a GLM with tree stage as a fixed factor. All data were statistically analysed with SPSS 11.0.

\section{Results}

Cynodon species covered $62 \%$ of the vegetation under tree canopies (Table 1). The other two abundant species under trees were Panicum maximum and Cenchrus ciliaris. The remaining $20 \%$ was covered mainly by herb species. Around tree canopies the vegetation was more species rich with six more or less abundant grass species (see Table 1). In open grassland, the vegetation consisted almost exclusively of the grass species Heteropogon contortis and Sehima nervosum. Percentage of live and dead stem and dead leaves was similar under and outside trees. Percentage of live leaves, however, was higher under trees compared to around trees and open grassland.

Forage quality was much higher under large tree canopies than in open grassland. This was indicated by higher leaf/stem ratios, higher concentrations of protein and DOM and lower NDF concentrations (Table 2, Fig. 1). For example, digestibility of green leaf organic matter (DOM) was highest in Cynodon grasses growing under the canopy where $70 \%$ of green leaves was digestible (Table 1) and DOM was lowest in $H$. contortis growing in open grassland. For NDF a reversed pattern was observed with the lowest values for Cynodon spp. and highest for $H$. contortis and $S$. nervosum. Protein contents of grasses were highest under tree canopies and Cynodon spp. and Cenchrus ciliaris showed a higher protein content under than around tree canopies. Forage quality of grasses growing around tree canopies was also higher than in grasses from open field but lower than under canopies. Leaf/stem ratios, protein concentration and DOM were all higher around trees canopies than in open field. $\mathrm{P}$ concentrations showed a different pattern: concentrations were higher in grasses

Table 2 Average (SD in parentheses) of digestibility of organic matter (DOM), neutral detergent fibre (NDF), protein and nutrient concentrations of grass species growing under and around canopies of large A. tortilis trees and in open grassland patches

\begin{tabular}{|c|c|c|c|c|c|c|c|c|}
\hline $\begin{array}{l}\text { Location } \\
\text { Data }\end{array}$ & Species & DOM (\%) & $\operatorname{NDF}(\%)$ & $\begin{array}{l}\text { Protein } \\
(\mathrm{mg} / \mathrm{g})\end{array}$ & $\mathrm{P}(\mathrm{mg} / \mathrm{g})$ & $\mathrm{K}(\mathrm{mg} / \mathrm{g})$ & $\mathrm{Ca}(\mathrm{mg} / \mathrm{g})$ & $\mathrm{Mg}(\mathrm{mg} / \mathrm{g})$ \\
\hline \multirow[t]{3}{*}{ Under tree canopy } & P. maximum & $65.7(6.5)$ & $70.6(3.3)$ & $141(19.7)$ & $1.77(0.17)$ & $40.6(2.2)$ & $4.12(0.26)$ & $3.25(0.79)$ \\
\hline & Cynodon spp. & $70.3(7.2)$ & $61.5(4.9)$ & $165(8.4)$ & $1.80(0.32)$ & $38.4(2.4)$ & $6.91(0.71)$ & $2.44(0.57)$ \\
\hline & Cenchrus ciliaris & $59.8(3.2)$ & $70.1(5.0)$ & $137(5.0)$ & $1.74(0.18)$ & $44.8(3.8)$ & $4.34(2.19)$ & $1.95(0.43)$ \\
\hline \multirow[t]{6}{*}{ Around tree canopy } & Cynodon spp. & $65.1(12.4)$ & $66.5(8.6)$ & $127(26.2)$ & $2.38(0.42)$ & $36.1(11.2)$ & $6.70(2.18)$ & $2.58(0.38)$ \\
\hline & Cenchrus ciliaris & $58.0(9.0)$ & $71.5(6.1)$ & $106(15.4)$ & $2.43(0.07)$ & $41.9(7.0)$ & $3.30(0.65)$ & $1.87(0.38)$ \\
\hline & D. macroblephera & $62.6(8.0)$ & $72.9(6.2)$ & $75(13.5)$ & $2.85(0.52)$ & $38.6(1.5)$ & $3.75(0.76)$ & $2.26(0.55)$ \\
\hline & Chloris virgata & $66.8(5.9)$ & $70.4(4.1)$ & $105(5.0)$ & $2.59(0.61)$ & $37.6(1.8)$ & $4.91(0.30)$ & $3.03(0.45)$ \\
\hline & U. mosambicencis & $69.1(5.4)$ & $64.8(3.5)$ & $104(10.3)$ & $3.59(0.78)$ & $44.3(3.9)$ & $5.28(0.56)$ & $4.00(0.40)$ \\
\hline & H. contortis & $57.0(4.8)$ & $70.2(3.0)$ & $82(11.8)$ & $1.46(0.13)$ & $17.2(0.5)$ & $3.30(0.3)$ & $1.64(0.18)$ \\
\hline \multirow[t]{2}{*}{ Open grassland } & H. contortis & $51.7(2.2)$ & $74.0(2.2)$ & $68(9.3)$ & $1.65(0.19)$ & $15.1(0.7)$ & $3.31(0.31)$ & $1.22(0.15)$ \\
\hline & S. nervosum & $54.7(1.0)$ & $74.6(1.0)$ & $61(9.7)$ & $1.46(0.13)$ & $12.0(0.8)$ & $4.67(0.36)$ & $1.47(0.06)$ \\
\hline \multicolumn{9}{|l|}{ Statistics $^{\mathrm{a}}$} \\
\hline Location & $F$ & $10.4 * * *$ & $5.55 * *$ & $49.9 * * *$ & $11.7 * * *$ & $28.2 * * *$ & 1.34 & $7.77 * *$ \\
\hline Tree (block) & $F$ & $7.08 * * *$ & $5.45 * * *$ & 1.36 & 1.07 & 1.36 & 0.64 & 0.71 \\
\hline
\end{tabular}

$* * P<0.01, * * * P<0.001$

a Variance of data was analysed with a GLM with grass species and location (open grassland and under and around canopies) as fixed factors 


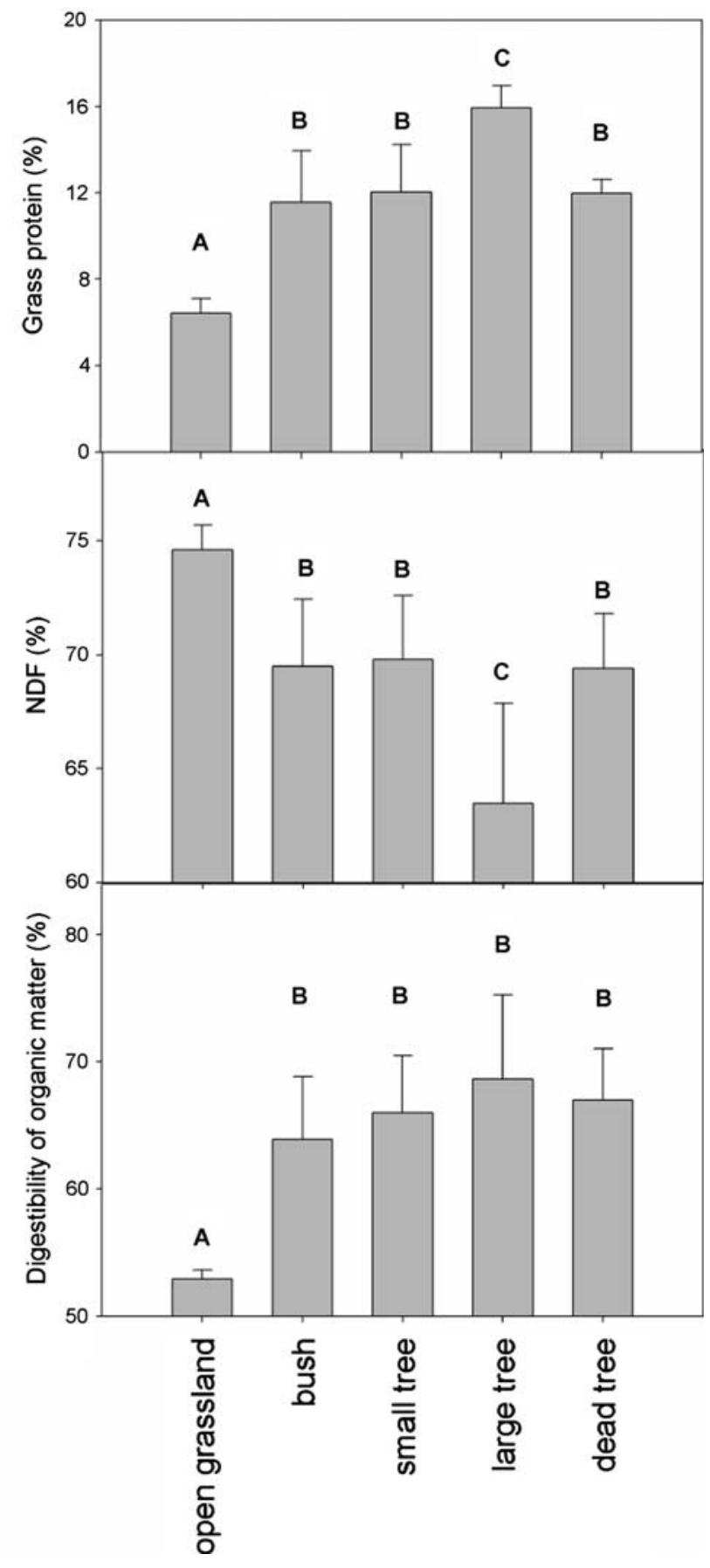

Fig. 1 Indicators of forage quality of grasses growing under different sized Acacia tortilis trees, dead trees and in open grassland. Mean (+SD) protein, digestibility of organic matter and neutral detergent fibre $(N D F)$ concentrations of green grass leaves. Bars with the same letter are not significantly different (LSD test, $P>0.05$ )

growing around canopies than under canopies and in open grassland (Table 1).

Protein concentration, NDF and DOM differed significantly between different tree stages $(P<0.05)$. Protein concentrations were highest under large trees and lowest in open grassland (Fig. 1). Smaller Acacia (bushes and small trees) showed intermediate values. Under dead trees grass protein concentrations were higher than in open grassland but lower than under large trees. DOM percentages showed a similar trend to protein concentrations; under small Acacia trees and bushes DOM of grasses was higher than in open grassland but lower than under large trees. NDF values showed the opposite trend with lowest values under large trees and highest values in open grassland (Fig. 1). NDF values of grasses growing under bushes and small and dead trees were lower than in open grassland but not significantly different from those of grasses growing under large trees. In general, these patterns show that forage quality increased with tree age and size. Under dead trees forage quality was higher than in open grassland but lower than under large trees.

Results from the linear programming model show that by selecting forage from under large tree canopies wildebeest can meet all their energy, nutrient and protein requirements before reaching their maximum intake determined by the grass fibre concentration (Fig. 2). Wildebeest can also satisfy their requirements for nutrients, protein and energy by selecting grass around tree canopies. However, the results of the linear programming model indicate they cannot do so by selecting food exclusively from open grassland. Due to the relatively high fibre content in forage from open grassland the maximum intake for wildebeest is about $3,700 \mathrm{~g} /$ day. Due to the low nutrient and protein concentrations in grasses from the open field, this amount is not enough to satisfy all the dietary requirements for wildebeest. All requirements can be satisfied by combining forage from open grassland with either forage from under or around tree canopies. Especially if forage from open grassland is combined with grass from under large tree canopies only a relatively small amount (10-20\%) of forage is required from under trees and the rest of the forage can be selected from open grassland (Fig. 2).

\section{Discussion}

Our results show that the forage quality of the herbaceous layer is much higher under trees than in open grassland. Grasses growing under tree canopies contained a lower fibre content and the highest concentrations of protein and $\mathrm{Ca}$ and had a higher digestible organic matter content. The higher forage quality under trees is partly caused by the different species which dominate the vegetation under large trees. However, Cynodon spp. growing under trees also had higher protein concentrations and DOM contents than the same species growing around tree canopies. This shows that a higher below-crown forage quality it is not only a species effect but also due to a different environment under trees. 

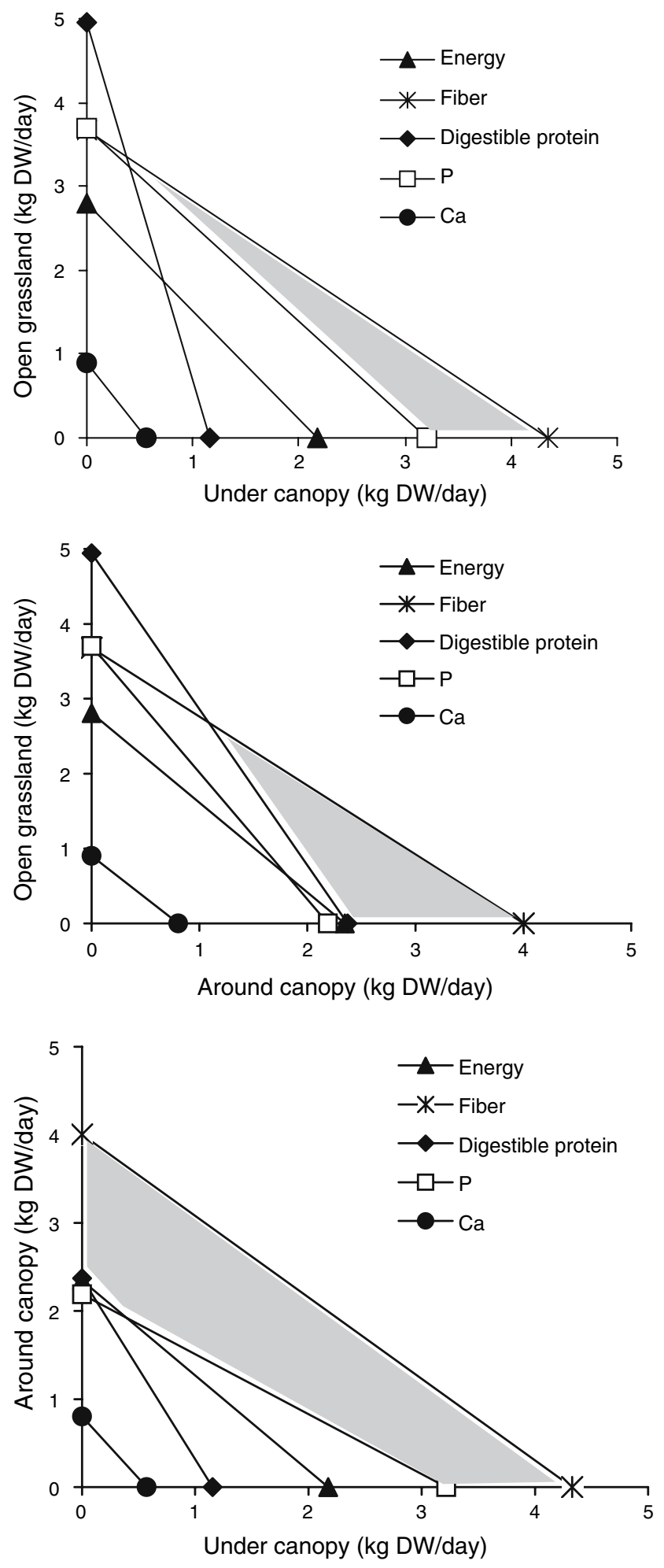

The positive effect of trees on forage quality did not stop at the canopy edge. Grasses around tree canopies still had higher nutrient concentrations and leaf/stem ratios and a higher DOM than the two species dominating open grassland. The grasses we sampled around tree canopies were growing about $7-10 \mathrm{~m}$ from the canopy edge. So one
Fig. 2 Results of a linear programming model, predicting whether wildebeest can meet their daily requirements for energy, nutrients and protein by selecting forage from under tree canopies, around tree canopies, or in open grassland patches. Within this model the minimum daily amount of energy, protein, $\mathrm{P}$ and $\mathrm{Ca}$ needed by wildebeest is defined. The lines indicate the minimum food intake needed to meet these requirements for a combination of two of the three food sources available. For fibre the maximum food intake is shown. The maximum and minimum intakes rates are calculated using Eqs. 2, 5, 7, 8 and 9. The shaded part indicates all possible combinations of food sources which meet nutrient, energy and protein requirements without exceeding maximum intake rates determined by the fibre content. $D W$ Dry weight

mature Acacia tree with a canopy diameter of $15 \mathrm{~m}$ can potentially increase forage quality over an area of more than $600 \mathrm{~m}^{2}$.

Our results could have been affected by the fact that we only sampled once. However plant samples taken in 2 previous years during different periods within the season show much higher nutrient concentration in grasses under trees compared to open grassland (Ludwig et al. 2001, 2004a). So it is likely that forage quality is higher under trees throughout the season.

Increased forage quality under savanna trees can be caused by a range of different effects because savanna trees influence the availability of all major resources used by grasses. Trees reduce light availability through shade, often increase soil nutrient concentrations, and compete with grasses for belowground resources, especially water (Belsky 1994; Scholes and Archer 1997; Anderson et al. 2001). Shade alone can already increase forage quality (Cruz et al. 1999). For example, two independent studies showed that $\mathrm{N}$ concentrations were increased in $P$. maximum growing under artificial shade (Deinum et al. 1996; Durr and Rangel 2000). However, probably most important is the higher soil nutrient availability under savanna trees. In a previous study, under the same Acacia trees, we found that concentrations of all major nutrients were higher under trees compared to open grassland (Ludwig et al. 2004a). Higher soil nutrient concentrations increase plant nutrient concentrations which improve the forage quality. Higher soil nutrient concentrations usually also increase grass productivity which would result in reduced plant nutrient concentrations due to dilution. However, grass productivity under these Acacia trees is mainly limited by water. Previous studies showed that soils under Acacia trees had lower soil moisture contents and soil water potentials than soils beyond the edge of canopies (Ludwig et al. 2003, 2004a). Higher forage quality under these savanna trees is probably caused by a combination of reduced soil moisture and increased nutrient availability.

The results of the linear model show the importance of the higher forage quality from under and around trees for 
large herbivores. When wildebeest forage only in open grassland, they cannot satisfy all their nutritional and energy requirements to maintain a stable body weight. The grass species growing in open grassland have a high fibre content which limits the maximum daily intake. Due to this limited intake insufficient amounts of protein and $\mathrm{P}$ can be extracted. Most of the available data on energy and nutrient requirements originate from agricultural studies and still few data are available for wild herbivores. For our model, we adjusted daily intake requirement for wildebeest from agricultural data in combination with experimental work on wildebeest (Murray 1993). These adjustments could have resulted in some errors in the model. For example the maximum NDF intake used originated from cattle and could be different for wildebeest. Also only one standard value for energy contents of grasses was used because no other data were available. Due to the large differences in forage quality of grasses from under trees compared to the open field, it is unlikely that a small change in model parameters or input values will significantly affect the conclusion that wildebeest need at least some forage from under trees. For example, wildebeest would have to increase their fibre intake by more than $35 \%$ to satisfy their protein needs in open grassland, and only if their protein needs were $30 \%$ less than assumed in our model could wildebeest satisfy their needs without grazing under or around trees. Another indication that large herbivores would need to forage under trees is that the crude protein concentration is below $7 \%$ in grasses from open grassland. At these protein concentrations the digestion rate is severely limited for all herbivores (Van Soest 1994) which suggests that large herbivores cannot survive when foraging from open grassland only. These results show the importance of trees for the functioning of savanna ecosystems and many large grazers probably depend indirectly on large trees for their long-term survival.

Trees are not the only source of spatial heterogeneity in forage quality. For example also termite hills, faeces concentrations and rivers can increase nutrient availability and thus improve forage quality (Grant and Scholes 2006). So in the absence of trees, large herbivores could forage in these "hot spots" to satisfy their nutrient requirements. However, trees cover a much larger part of the landscape than other sources of spatial heterogeneity and are thus particularly important in improving forage quality. In the absence of trees, herbivores can increase forage quality through positive feedbacks of grazing (Augustine and McNaughton 2006). For example through the formation of grazing lawns (McNaughton 1985) However, these positive feedbacks are mainly observed in nutrient-rich savannas and grasslands such as the Serengeti (Grant and Scholes 2006).
Forage quality of grasses growing around dead trees was lower than under large trees but still higher than in open grassland. Grass protein concentrations, for example, were almost twice as high around dead trees as in open grassland. So, forage quality does not dramatically decline immediately after trees die. This might explain why negative effects of tree removal have largely been ignored. In a previous study, we also showed that grass biomass production is higher around dead trees than in open grassland and under large trees due to the lingering positive effect of trees (increased soil nutrient availability persists for some years), combined with the removal of negative effects such as shade and competition for water (Ludwig et al. 2004a). Thus, the first impression after trees are cut down/killed is that trees were suppressing grass production.

When the positive effect of higher soil nutrient concentrations around dead trees has disappeared, grass forage quality and productivity will be as currently found in open grassland, where both productivity and quality are lower than under trees that died recently. So only after a time lag of at least 8 years (Ludwig et al. 2004a), when the effect of trees on forage quality has disappeared, does it become clear that tree felling only temporarily increases grass biomass and ultimately reduces forage quality, thereby jeopardising animal productivity. Large trees killed by elephants or human pressure can be replaced by regenerating small trees or bushes; however, their impact on grass quality and availability is different from that of large trees. Bushes tend to reduce grass production (Ludwig et al. 2004a) and have a smaller positive effect on forage quality than large trees. Grass forage quality under the small trees was also still significantly lower than under large trees. The small trees we used for our study were about 20 years old so it will take more than two decades before forage quality will be as good as before clearing. Another problem is that the contradictory effects of different sized trees on grass quality and production can encourage bush-clearing. Increased grass production after large tree removal suggests that trees negatively affect grass production. After clearing the large trees, regenerating bushes start to repress grass production which again encourages removal of all woody species. Bush-clearing is, however, ultimately counterproductive because it will result in savannas with few or no large trees and thus a much lower forage quality.

Over the last 20 years, numbers of elephants have increased in several NPs in Africa (Van de Vijver et al. 1999; Eckhardt et al. 2000; Skarpe et al. 2004). This increase can have serious effects on other large herbivores. For example, the increase in the number of African elephants in Kruger NP which took place over the last 50 years, and the consequent reduction in the number of large trees (Eckhardt et al. 2000) could have caused the demise of rare selective antelopes such as the roan. Roan 
largely depend on forage from P. maximum (Heitkonig 1994), a grass species which dominates the vegetation under trees in southern African savannas (Ruess and Halter 1990; Scholes and Walker 1993; Scholes and Archer 1997; Eckhardt et al. 2000). As the effects of tree removal only become clear years after trees die, impacts of increased elephant pressure might not be clear at the moment but could become a serious problem in the near future.

In conclusion, our results presented here show that savanna trees have an important role in affecting the quality of forage available for wildebeest in Tarangire NP. Some recent work shows that forage quality is also higher under trees in other African savannas and more future work should show how general our results are (Treydte et al. 2007). As trees increase food quality for herbivores the reduction in the number of large trees observed in savannas across Africa (Van de Vijver et al. 1999; Eckhardt et al. 2000; Mosugelo et al. 2002) can have serious consequences for the survival of large herbivores. These negative effects of tree removal are probably usually not recognised because forage quality only slowly reduces after trees die. However, better protection of large trees in savanna ecosystems could be necessary to sustain current numbers of large herbivores.

Acknowledgements The Tanzanian Commission for Science and Technology (COSTECH), the Tanzania Wildlife Research Institute (TAWIRI) and Tanzania NPs (TANAPA) kindly gave permission to work in Tarangire NP. We would like to thank Exaud Nassari, Michael Karengi and Albert Lucas for excellent help in the field. This research was financed by the Netherlands Foundation for the Advancement of Tropical Research (WOTRO). All experiments comply with the current laws of the country in which they were performed.

Open Access This article is distributed under the terms of the Creative Commons Attribution Noncommercial License which permits any noncommercial use, distribution, and reproduction in any medium, provided the original author(s) and source are credited.

\section{References}

Amundson RG, Ali AR, Belsky AJ (1995) Stomatal responsiveness to changing light intensity increases rain-use efficiency of belowcrown vegetation in tropical savannas. J Arid Environ 29:139153

Anderson LJ, Brumbaugh MS, Jackson RB (2001) Water and treeunderstorey interactions: a natural experiment in a savanna with oak wilt. Ecology 82:33-49

Augustine DJ McNaughton SJ (2006) Interactive effects of ungulate herbivores, soil fertility and variable rainfall on ecosystem processes in a semi-arid savanna. Ecosystems 9:1242-1256

Belovsky GE (1978) Diet optimization in a generalist herbivore: the moose. Theoret Popul Biol 14:105-134

Belsky AJ (1992) Effects of trees on nutritional quality of understory gramineous forage in tropical savannas. Trop Grassl $26: 12-20$
Belsky AJ (1994) Influences of trees on savanna productivity: test of shade, nutrients, and tree-grass competition. Ecology 75:922932

Belsky AJ, Amundson RG, Duxbury JM, Riha SJ, Ali AR, Mwonga SM (1989) The effects of trees on their physical, chemical, and biological environments in a semi-arid savanna in Kenya. J Appl Ecol 26:1005-1024

Belsky AJ Mwonga SM, Amundson RG, Duxbury JM, Ali AR (1993) Comparative effects of isolated trees on their undercanopy environments in high- and low-rainfall savannas. J Appl Ecol 30:143-155

Caldwell MM, Dawson TE, Richards JH (1998) Hydraulic lift: consequences of water efflux for the roots of plants. Oecologia 113:151-161

Clayton WD, Renvoize SA (1982) Flora of Tropical East Africa, Gramineae (part 1-3)

Crampton EW, Harris LE (1969) Applied animal nutrition-the use of feedstuffs in the formulation of live stock ratios, 2nd edn. Freeman, San Francisco, Calif.

Cruz P, Sierra J, Wilson JR, Dulormne M, Tournebize R (1999) Effects of shade on the growth and mineral nutrition of tropical grasses in silvopastoral systems. Ann Arid Zone 38:335-361

Deinum B, Sulastri RD, Zeinab MHJ, Maasen A (1996) Effect of light intensity on growth, anatomy and forage quality of two tropical grasses (Brachiaria brizantha and Panicum maximum var trichoglume). Neth J Agric Sci 44:111-124

Durr PA, Rangel J (2000) The response of Panicum maximum to a simulated subcanopy environment. Trop Grassl 34:110-117

Eckhardt HC, Van Wilgen BM, Biggs HC (2000) Trends in Woody vegetation cover in the Kruger national park, South Africa, between 1940 and 1998. Afr J Ecol 38:108-115

Grant CC, Scholes MC (2006) The importance of nutrient hot-spots in the conservation and management of large wild mammalian herbivores in semi-arid savannas. Biol Conserv 130:436-437

Goering HK, Van Soest P J (1970) Forage fiber analysis: apparatus, reagents, procedures and some application. Agricultural handbook no. 379. United States Department of Agriculture, Washington, D.C.

Heitkonig IMA (1994) Feeding strategy of Roan antelope (Hippotragus equinus) in a low nutrient savanna. $\mathrm{PhD}$ thesis, University of Witwatersrand, Johannesburg

Jackson J, Ash AJ (1998) Tree-grass relationship in open eucalypt woodlands of northeastern Australia: influence of trees on pasture productivity, forage quality and species distribution. Agrofor Syst 40:159-176

Kellman M (1979) Soil enrichment by neotropical savanna trees. J Ecol 67:565-577

Kituyi E, Marufu L, Wandiga SO, Jumba IO, Andreaea MO, Helas G (2001) Biofuel availability and domestic use patterns in Kenya. Biomass Bioenergy 20:71-82

Ludwig F, De Kroon H, Prins HHT, Berendse F (2001) The effect of nutrients and shade on tree-grass interactions on an East African savanna. J Veg Sci 12:579-588

Ludwig F, Dawson TE, De Kroon H, Prins HHT, Berendse F (2003) Hydraulic Lift in Acacia tortilis trees on an East African savanna. Oecologia 134:293-300

Ludwig F, De Kroon H, Berendse F, Prins HHT (2004a) The influence of savanna trees on nutrient, water and light availability and the understorey vegetation. Plant Ecol 170:93-105

Ludwig F, Dawson T E, Prins HHT, Berendse F, De Kroon H (2004b) Belowground competition between trees and grasses may overwhelm the facilitative effects of hydraulic lift. Ecol Lett 7:623-631

Luoga EJ, Witkowski ETF, Balkwill K (2002) Harvested and standing wood stocks in protected and communal miombo woodlands of eastern Tanzania. For Ecol Manage 164:15-30 
McNaughton SJ (1985) Ecology of a grazing ecosystem: the Serengeti. Ecol Monogr 55:259-294

Mordelet P, Menaut JC (1995) Influence of trees on above-ground production dynamics of grasses in a humid savanna. J Veg Sci 6:223-228

Mosugelo DK, Moe SR, Ringrose R, Nelleman C (2002) Vegetation changes during a 36-year period in northern Chobe National Park, Botswana African. J Ecol 40:232-240

Murray MG (1993) Comparative nutrition of wildebeest, hartebeest and topi in the Serengeti. Afr J Ecol 31:172-177

Murray MG (1995) Specific nutrient requirements and migration of wildebeest. In: Sinclair ARE, Arcese P (eds) Serengeti II: dynamics, management and conservation of an ecosystem. The University of Chicago Press, Chicago, Ill., pp 231-256

Novozamski I, Houba VJG, Van Eck R, Van Vark W (1983) A novel digestion technique for multi-element plant analysis. Commun Soil Sci Plant Anal 14:239-249

Olff H, Ritchie JT, Prins HHT (2002) Global environmental controls of diversity in large herbivores. Nature 415:901-904

Prins HHT (1987) The Buffulo of Manyara, the individual in the context of herd life in a seasonal environment of East Africa. $\mathrm{PhD}$ thesis, Rijksuniversiteit Groningen

Prins HHT (1996) Ecology and behaviour of the African buffalo. Chapman Hall, London

Prins HHT, Olff H (1998) Species richness of African grazer assemblages: towards a functional explanation In: Newbery DM, Prins HHT, Brown N (eds) Dynamics of tropical communities. Blackwell, Oxford, pp 449-490

Prins HHT, Van der Jeugd HP (1993) Herbivore population crashes and woodland structure in East Africa. J Ecol 81:305-314

Reid RL, Jung GA, Thayne WV (1988) Relationships between nutritive quality and fiber components of cool season and warm season forages: a retrospective study. J Anim Sci 66:1275-1291

Ruess RW, Halter FL (1990) The impact of large herbivores on the Seronera woodlands, Serengeti National Park, Tanzania. African. J Ecol 28:259-275

Scholes RJ, Archer SR (1997) Tree-grass interactions in savannas. Annu Rev Ecol Syst 28:517-544
Scholes RJ, Walker B H (1993) An African savanna: synthesis of the Nylsvley study. Cambridge University Press, Cambridge

Skarpe C, Aarrestad PA, Andreassen HP, Dhillion S, Dimakatso T, Du Toit JT, Halley DJ, Hytteborn H, Makhabu S, Mari M, Marokane W, Masunga G, Modise D, Moe SR, Mojaphoko R, Mosugelo D, Motsumi S, Neo-Mahupeleng G, Ramotadima M, Rutina L, Sechele L, Sejoe TB, Stokke S, Swenson JE, Taolo C, Vandewalle M, Wegge P (2004) The return of the giants: ecological effects of an increasing elephant population. Ambio $33: 276-282$

Tarangire Conservation Project (1997) Analysis of migratory movements of large mammals and their interaction with human activities in the Tarangire area in Tanzania as a contribution to a conservation and sustainable development

Tilley JMA,Terry RA (1963) A two stage technique for the in vitro digestion of forage crops. J Br Grassland Soc 18:104-111

Treydte AC, Heitkönig IMA, Prins HHT, Ludwig F (2007) Trees enhance grass quality for herbivores in African savannas Perspect Plant Ecol Evol Syst 8:197-205

Van de Vijver CADM (1999) Fire and life in Tarangire, effects of burning and herbivory on an East African savanna system. $\mathrm{PhD}$ thesis, Wageningen University

Van de Vijver CADM, Foley CA, Olff H (1999) Changes in the woody component of an East African savanna during 25 years. J Trop Ecol 15:545-564

Van Soest PJ (1994) Nutritional ecology of the ruminant, 2nd edn. Cornell University Press, Ithaca, N.Y.

Voeten MM (1999) Living with wildlife: coexistence of wildlife and livestock in an East African savanna system. $\mathrm{PhD}$ thesis, Wageningen University

Voeten MM, Prins HHT (1999) Resource partitioning between sympatric wild and domestic herbivores in the Tarangire region of Tanzania. Oecologia 120:287-294

Wallis de Vries MF (1995) Estimating forage intake and quality in grazing cattle: a reconsideration of the hand-plucking method. J Range Manage 48:370-375 